\title{
NEUROCYSTICERCOSIS IN CHILDREN PRESENTING WITH AFEBRILE SEIZURE: CLINICAL PROFILE, IMAGING AND SERODIAGNOSIS
}

\author{
Priyadarshi Soumyaranjan SAHU(1,3), Jyotsna SEEPANA(1), Sudarsini PADELA(2), Abani Kanta SAHU(2), Swarna SUBBARAYUDU(1) \& Ankur BARUA(4)
}

\begin{abstract}
SUMMARY
Neurocysticercosis (NCC) is one of the major causes of childhood seizures in developing countries including India and Latin America. In this study neurological pediatric cases presenting with afebrile seizures were screened for anti-Cysticercus antibodies $(\operatorname{IgG})$ in their sera in order to estimate the possible burden of cysticercal etiology. The study included a total of 61 pediatric afebrile seizure subjects (aged one to 15 years old); there was a male predominance. All the sera were tested using a pre-evaluated commercially procured IgG-ELISA kit (UB-Magiwell Cysticercosis Kit ${ }^{T M}$ ). Anti-Cysticercus antibody in serum was positive in 23 of 61 (37.7\%) cases. The majority of cases with a positive ELISA test presented with generalized seizure (52.17\%), followed by complex partial seizure $(26.08 \%)$, and simple partial seizure $(21.73 \%)$. Headaches were the major complaint $(73.91 \%)$. Other presentations were vomiting $(47.82 \%)$, pallor (34.78\%), altered sensorium (26.08\%), and muscle weakness $(13.04 \%)$. There was one hemiparesis case diagnosed to be NCC. In this study one child without any significant findings on imaging was also found to be positive by serology. There was a statistically significant association found between the cases with multiple lesions on the brain and the ELISA-positivity ( $p=0.017$ ). Overall positivity of the ELISA showed a potential cysticercal etiology. Hence, neurocysticercosis should be suspected in every child presenting with afebrile seizure especially with a radio-imaging supportive diagnosis in tropical developing countries or areas endemic for taeniasis/cysticercosis.
\end{abstract}

KEYWORDS: Childhood seizure; Afebrile seizure; Cysticercosis; Neurocysticercosis; Serodiagnosis.

\section{INTRODUCTION}

Worldwide, one third of the total epilepsy cases arise in childhood and neurocysticercosis (NCC) is the major cause particularly in developing countries including India and Latin America ${ }^{20.30 .34}$. NCC is caused by the metacestode larval stage of Taenia solium, and it affects patients of all ages ${ }^{4}$. In India, NCC is the most common cause of convulsions and hydrocephalus in adults and is the single most common cause of community acquired active epilepsy ${ }^{16,22}$. NCC patients may remain asymptomatic for months to years, and commonly a diagnosis is made incidentally when neuro-imaging is performed. However, its manifestations are variable and somewhat different when it occurs in children $^{24,28}$.

NCC in children is believed to be infrequent, but, as methods of diagnosis (imaging techniques and immunological tests) have improved, it has become possible to confirm more cases $^{21}$. The serological tests are considered to be helpful as adjunct tests in order to confirm clinical diagnosis of NCC where Enzyme linked immunosorbent assay (ELISA) and enzyme linked immunotransfer blotting (EITB) are most frequently used for detection of antibodies in serum and/or $\mathrm{CSF}^{9,14,34}$. Though the latest diagnostic method approved by the Centers for Disease Control (CDC) for a confirmatory diagnosis of NCC is based on EITB, its cost and non availability of local suppliers limits its utility in India. In our study a sensitive ELISA kit is employed as a relatively lower cost screening test. There is insufficient information about NCC in children from Andhra Pradesh State in India. However, there are a couple of reports of T. solium cysticercosis in this state since a lot of adult cases of NCC as well as eye cases were reported earlier ${ }^{13,18,19}$ that indicate a possible prevalence of cysticercosis in children in the same region of this country. With this background, the objective of the present study was set to screen for antiCysticercus antibodies in serum to estimate the NCC prevalence as an underlying etiology of afebrile seizure in children by ELISA.

\section{MATERIALS AND METHODS}

The present study was conducted in a teaching hospital in Andhra Pradesh Province in India after due approval of the protocol and permission where a total of 61 pediatric subjects presenting with afebrile seizure were recruited in a two years period. Informed consent was obtained from the parents or legal guardians of each of the study subjects. Detailed history was then collected from each patient and/or guardian/

(1) Department of Microbiology, Alluri Sitarama Raju Academy of Medical Sciences, Eluru, Andhra Pradesh-534005, India.

(2) Department of Paediatrics, Alluri Sitarama Raju Academy of Medical Sciences, Eluru, Andhra Pradesh-534005, India.

(3) Division of Pathology, School of Medicine, International Medical University, 57000 Kuala Lumpur, Malaysia.

(4) Division of Community Medicine, School of Medicine, International Medical University, 57000 Kuala Lumpur, Malaysia.

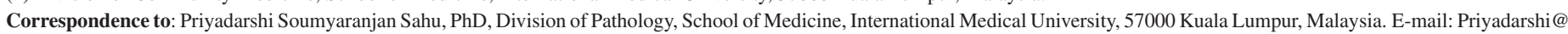
imu.edu.my; priyadarshi_sahu@yahoo.com. Phone: +60 32731 7406. Fax: +60 386567229 
SAHU, P.S.; SEEPANA, J.; PADELA, S.; SAHU, A.K.; SUBBARAYUDU, S. \& BARUA, A. - Neurocysticercosis in children presenting with afebrile seizure: clinical profile, imaging and serodiagnosis. Rev. Inst. Med. Trop. Sao Paulo, 56(3): 253-8, 2014.

parents. Each child was clinically examined and $3 \mathrm{~mL}$ blood samples were collected. The age range of patients was between one to 15 years with male predominance (male: female $=47: 14$ ). CT imaging was performed in all cases. The study subjects were initially hypothesized as possible cases of NCC based on two minor plus one epidemiological criteria as per the revised diagnostic criteria suggested elsewhere ${ }^{5}$.

A commercially procured ELISA kit (UB-Magiwell Cysticercosis $\mathrm{Kit}^{T M}$ ) was employed for detection of anti-Cysticercus antibodies in sera. All the collected sera were tested using the same ELISA kit following the manufacturer's instructions. Antigen coated wells supplied by the kit manufacturer were incubated with 1:10 diluted patient/control serum (diluted with the serum diluent fluid provided in the kit). A negative control serum, a low positive control serum and a high positive control serum (all supplied by the manufacturer) were also used for validity of the test. Absorbance was measured at $492 \mathrm{~nm}$. A sample was considered positive for anti $T$. solium antibody when the OD value was estimated to be more than that of the low positive control serum. The sensitivity and specificity of the above ELISA for anti-Cysticercus antibody detection in serum was previously estimated to be $85 \%$ and $94 \%$ respectively based on results of the test using sera from a group of known cases (cases with a definitive diagnosis of NCC) and another group comprising healthy normal individuals as described in an earlier study ${ }^{25}$. Positive control sera were confirmed as positive by radio-imaging features as well as CDC approved EITB test using a commercially procured kit (Immunetics Inc, USA).

\section{RESULTS}

A positive anti-Cysticercus IgG-ELISA result was observed in 23 of the total 61 children indicating an overall positivity of $37.7 \%$ (Table 1). The majority of cases with IgG-ELISA positive for Cysticercosis presented with generalized seizure $(66.6 \%)$, followed by complex partial seizure $(31.8 \%)$, and simple partial seizure $(41.1 \%)$ (Table 1$)$. The absorbance $\left(\mathrm{OD}_{450}\right)$ for Low and High positive control sera was measured to be 0.807 and 1.139 respectively. As per the manufacturer's specification, a case was confirmed as positive for anti-Cysticercus IgG antibody when its absorbance was observed to be greater than that of the Low positive control. A case was considered as borderline when its absorbance was observed to be same as that of the Low positive control. The mean $\mathrm{OD}_{450}$ values of the ELISA on sera identified to be positive or negative for anti-Cysticercus-IgG antibodies $n_{1}=23$ and $n_{2}=38$ respectively) were further analyzed using GraphPad QuickCalcs free statistical calculators available on web (http://www.graphpad. com/quickcalcs). The two-tailed $p$ value was estimated to be less than 0.0001 , hence this difference was considered to be extremely statistically significant. Intermediate values used in these calculations: $t=6.0864$; $\mathrm{df}=16$; Standard error of difference $=0.080$. Confidence interval: $95 \%$ confidence interval of this difference: From -0.65452761 to -0.31636439 .

The pattern of seizure and other clinical manifestations in the recruited cases vs. the ELISA-positive cases $(n=61$ and 23 respectively) are stated in Figure 1. Among the 23 cases with a positive ELISA result, the relative distribution of different seizure types was found to be similar to the overall cases. The majority of cases with IgG-ELISA positive for Cysticercosis presented with a generalized seizure (52.17\%), followed by complex partial seizure (26.08\%), and simple partial seizure $(21.73 \%)$. Headaches were the major complaint $(73.91 \%)$. Other presentations were vomiting (47.82\%), pallor $(34.78 \%)$, altered sensorium $(26.08 \%)$, and muscle weakness $(13.04 \%)$. There was one hemiparesis case diagnosed to be NCC. Results of the IgG-ELISA in patients with different patterns

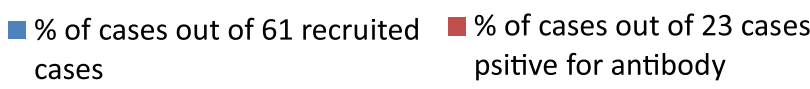

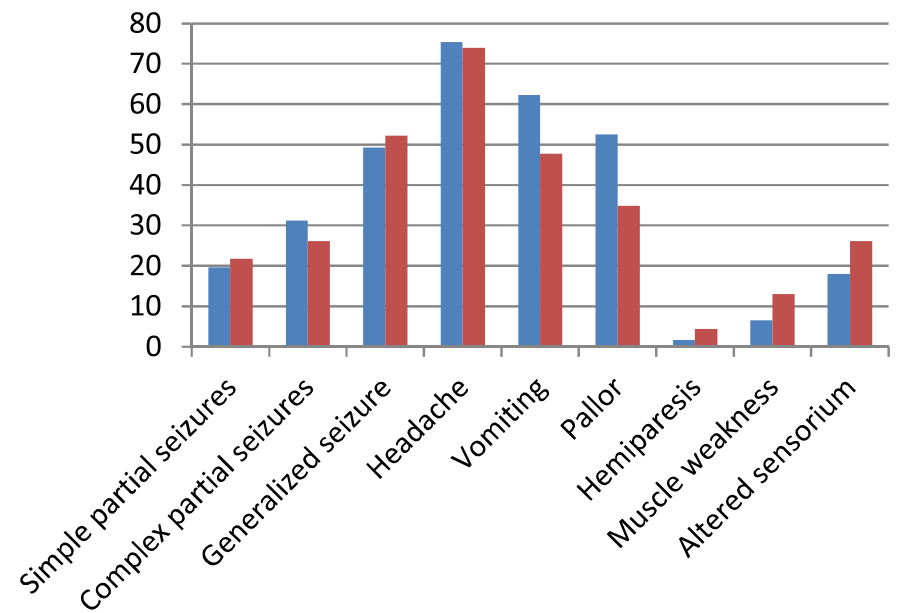

Fig. 1 - Distribution of clinical signs/symptoms, and seizure pattern in afebrile seizure cases diagnosed to be positive for anti-Cysticercus IgG-ELISA vs. all the recruited cases.

Table 1

Results of anti-Cysticercus IgG-ELISA in patients with different patterns of seizure

Type of seizure or seizure pattern

\section{Number of children recruited}

Anti-Cysticercus IgG-ELISA

$23(37.7)$
38 (62.3)

\begin{tabular}{|c|c|c|c|c|}
\hline \multirow{2}{*}{$\begin{array}{l}\text { Type of seizure or seizure } \\
\text { pattern }\end{array}$} & \multirow{2}{*}{$\begin{array}{l}\text { Number of children } \\
\text { recruited }\end{array}$} & \\
\hline & & $\begin{array}{l}\text { No. }(\%) \text { of sera } \\
\text { tested positive }\end{array}$ & $\begin{array}{l}\text { No. }(\%) \text { of sera } \\
\text { tested negative }\end{array}$ & $\begin{array}{c}\text { Statistical } \\
\text { analysis }\end{array}$ \\
\hline Simple partial seizures & 12 & $5(41.1)$ & $7(58.9)$ & \multirow{3}{*}{$\begin{array}{c}\chi^{2}=0.45 \\
\mathrm{df}=2 \\
p=0.798\end{array}$} \\
\hline Complex partial seizures & 19 & $6(31.8)$ & $13(68.2)$ & \\
\hline \multirow[t]{2}{*}{ Generalized seizure } & 30 & $12(66.6)$ & $18(33.4)$ & \\
\hline & Total $=61$ & $23(37.7)$ & $38(62.3)$ & \\
\hline
\end{tabular}

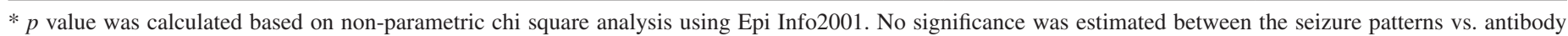
positivity $(p=0.798)$. 
SAHU, P.S.; SEEPANA, J.; PADELA, S.; SAHU, A.K.; SUBBARAYUDU, S. \& BARUA, A. - Neurocysticercosis in children presenting with afebrile seizure: clinical profile, imaging and serodiagnosis. Rev. Inst. Med. Trop. Sao Paulo, 56(3): 253-8, 2014.

Table 2

Results of anti-Cysticercus IgG-ELISA in patients with respect to CT scan imaging features

\begin{tabular}{|c|c|c|c|c|}
\hline & \multirow{2}{*}{$\begin{array}{c}\text { Total cases } \\
\mathrm{N}\end{array}$} & \multicolumn{3}{|c|}{ Anti-Cysticercus IgG-ELISA } \\
\hline & & $\begin{array}{l}\text { No. }(\%) \text { of sera } \\
\text { tested positive }\end{array}$ & $\begin{array}{l}\text { No. }(\%) \text { of sera } \\
\text { tested negative }\end{array}$ & $\begin{array}{c}\text { Statistical } \\
\text { analysis }\end{array}$ \\
\hline \multicolumn{5}{|l|}{ Number of lesions in brain $(n=61)$} \\
\hline Single lesion & 38 & $12(31.57)$ & $26(68.42)$ & \multirow{3}{*}{$\begin{array}{c}\chi^{2}=8.13 \\
\mathrm{df}=2 \\
p=0.017\end{array}$} \\
\hline Multiple lesions & 15 & $10(66.66)$ & $5(33.33)$ & \\
\hline \multirow[t]{2}{*}{ No lesion found (Normal Scan) } & 8 & $1(12.5)$ & $7(87.5)$ & \\
\hline & Overall result of 61 & $23(37.7)$ & $38(62.29)$ & \\
\hline
\end{tabular}

* $p$ value was calculated based on non-parametric chi square analysis using Epi Info2001; there was a statistical difference between the cases with single lesion vs those with multiple lesions in brain and the ELISA-positive results $(p=0.017)$. ** Number of lesions, and location was based on the CT features and of 61 total number of cases 53 cases presented with either one or more number of lesions in the brain whereas eight cases did not show any lesion (normal scan); $\mathrm{n}=$ total number of cases.

Table 3

Results of anti-Cysticercus IgG-ELISA in patients with respect to location of lesions in brain

\begin{tabular}{|c|c|c|c|c|}
\hline & \multirow[b]{2}{*}{ Total number of cases } & \multicolumn{3}{|c|}{ Anti-Cysticercus IgG-ELISA } \\
\hline & & $\begin{array}{l}\text { No. }(\%) \text { of sera } \\
\text { tested positive }\end{array}$ & $\begin{array}{l}\text { No. }(\%) \text { of sera } \\
\text { tested negative }\end{array}$ & $\begin{array}{c}\text { Statistical } \\
\text { analysis }\end{array}$ \\
\hline \multicolumn{5}{|c|}{ Location of lesions in brain $(n=53)$ no lesion found in 8 cases } \\
\hline Parietal & 27 & $12(44.44)$ & $15(55.55)$ & \multirow{4}{*}{$\begin{array}{c}\chi^{2}=0.9 \\
\mathrm{df}=3 \\
p=0.826\end{array}$} \\
\hline Occipital & 7 & $3(42.82)$ & $4(57.14)$ & \\
\hline Fronto-perietal & 6 & $3(50)$ & $3(50)$ & \\
\hline \multirow[t]{2}{*}{ Frontal } & 13 & $4(30.76)$ & $9(69.23)$ & \\
\hline & Overall result of 53 & $22(41.5)$ & $31(58.49)$ & \\
\hline
\end{tabular}

* $p$ value was calculated based on non-parametric chi square analysis using Epi Info2001; no statistical difference was found when the relative distribution was compared among different parts of the brain $(p=0.826)$. ** The lesion location was based on the CT features and of 53 cases presented with either one or more number of lesions in the brain; $\mathrm{n}=$ total number of cases.

of seizure showed predominance of generalized type but no statistical difference was observed (Table 1).

The CT scan findings i.e., number, distribution of lesions, and respective ELISA results are summarized in Table 2 and 3. The majority $(n=38)$ of the cases presented with a single space occupying lesion and 15 cases with more than two lesions based on CT scan report. In eight cases the CT scan was reported normal; one child found to be positive by serology.

The distribution of lesions in various parts of the brain showed the majority were in the parietal lobe followed by frontal, occipital, frontoparietal lobes (Table 3).

Of 23 positive cases, only 22 had a CT scan report showing presence of lesion(s) on the brain. The majority of cases had a calcified cyst (nine cases single and nine cases multiple). Among the cases with single or multiple lesions, the type of lesion and presence or absence of inflammation is shown in Table 4. There was active inflammation around the lesion in 11 cases (one vesicular, nine nodular cases) and four cases with calcified mass. None of the cases with vesicular lesion tested positive for antibody.
Among the positive cases there were 16 male and 7 female children. The overall age range of the patients was found to be one to 15 years (median age $=11$ years). The age range of male cases was one to 14 years (median age $=11$ years) and the age range of female cases was from six to 15 years (median age $=12$ years).

\section{DISCUSSION}

$\mathrm{NCC}$ is the main cause of seizures in adults in many developing countries including South and Southeast $\mathrm{Asia}^{23}$. However, pediatric cases are seldom explored. Our study showed generalized seizures appeared in the majority of cases compared to partial seizures among the children presented to our pediatric epilepsy clinic. Results out of the present study supported the assumption that NCC can be a potential cause of childhood epilepsy particularly in tropical countries. In Mexico seizures were reported to be more frequent in children compared to adults, and intracranial hypertension and headaches were more frequent in adults ${ }^{24}$. In a study in Mexico, they identified different causes underlying the different distribution of seizures and intracranial hypertension in the two patient groups. But the situation has not been clarified for the pediatric population universally ${ }^{8}$. In a recent report from another Indian province, 


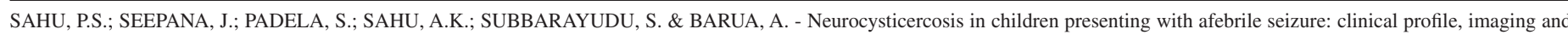
serodiagnosis. Rev. Inst. Med. Trop. Sao Paulo, 56(3): 253-8, 2014.

Table 4

Type or stage of the lesion in cases tested positive by anti-Cysticercus IgG-ELISA

\begin{tabular}{llc}
\hline $\begin{array}{l}\text { Number of } \\
\text { lesions }\end{array}$ & Lesion type & $\begin{array}{l}\text { No. (\%) of sera tested } \\
\text { positive by anti-Cys- } \\
\text { ticercus IgG-ELISA }\end{array}$ \\
\hline \multirow{2}{*}{ Single lesion } & $\begin{array}{l}\text { Vesicular } \\
\text { Granular-nodular } \\
\text { (with inflammation) }\end{array}$ & -nil- \\
& Calcified cyst (single) & $3(13.7)$ \\
$>1$ lesions & $\begin{array}{l}\text { Calcified cysts (>1) } \\
\text { Calcified + granular nodular } \\
\text { stage (with inflammation) }\end{array}$ & $9(40.9)$ \\
\hline & $\begin{array}{l}\text { Total number of positive cases } \\
\text { with brain lesion }\end{array}$ & $9(40.9)$ \\
\hline
\end{tabular}

* $p$ value was calculated and analyzed using GraphPad QuickCalcs free statistical calculators; no statistical difference was found when the types of lesions (calcified lesions only vs. non-calcified lesions) were compared with respect to ELISA positivity. The two-tailed $p$ value equals 0.7215 . ** The type of lesion was based on the $\mathrm{CT}$ features following the criteria as described elsewhere

$89.66 \%$ cases having neurological manifestations with inflammatory granulomas were found consistent with diagnosis of $\mathrm{NCC}^{1}$. However, the serodiagnostic confirmation was not performed in these cases. One strange case in the present series was a one year old patient that was diagnosed to be positive by serology. However a recent report of a 2-yearold boy with diagnosis of NCC in Ecuador could support our finding that such a young child can also acquire this infection. The Ecuador case presented with two parenchymal brain ring-enhancing lesions and was confirmed by positive serology as well response to albendazole therapy where the patient's mother was a Taenia solium carrier ${ }^{6}$. However, in the one year old child the source of infection was not identified since the mother refused to reveal her health history and, in addition that patient was referred elsewhere.

It has been accepted that the abrupt onset of clinical signs in human NCC coincides with intense pathologic reactions to degenerating metacestodes in the brain ${ }^{15}$. Following the death of all cysts, provoked seizures disappear, leaving a smaller percent of patients with residual epilepsy $^{20}$. In the present study calcified lesions on the brain were observed in the majority of the cases which included either a single lesion or multiple ones, and also either with or without peri-lesional edema. Inflammation surrounding the lesions indicates the disease to be resulted primarily from the host inflammatory response to dying parasites as suggested elsewhere ${ }^{35}$. Generalized epilepsy was the most common clinical presentation in the present study. Earlier study also showed a predominance of generalized seizures compared to other clinical symptoms and also significantly higher titre in confirmed patients of NCC as compared to patients with other neurological disorders and normal controls $^{26}$. Though NCC patients present with focal seizures the trend of generalized seizures to be the major presentation in children having NCC is contradictory to an earlier Indian study ${ }^{31}$. Hence, this study indicates that NCC should be suspected in every child with seizures especially in endemic areas. In the present study, only altered sensorium was found in $26.8 \%$ children with positive serology testing. Similar incidence was also reported in children from the earlier Indian study ${ }^{12}$.

In pediatric NCC patients, single colloidal parenchymal cysts were the most common radiologic findings compared with adults in whom multiple viable parasites in the basal subarachnoidal cisterns or in the ventricles were seen in Mexico ${ }^{24}$. An increased number of vesicular cysticerci and decreased number of degenerating cysticerci correlating with aging were noticed in earlier study, where immuno-endocrinological factors may be playing a role in susceptibility and pathogenesis ${ }^{7}$. However, in the present study, among the positively diagnosed children, we did not find any such trend. It may be clearer if we compare the prevalence among both children and adults in our future studies. We found the majority of cases had cyst(s) in the parietal region of the brain. In an earlier report from India it was hypothesized that a child with partial seizures with no obvious causation has a high probability of harboring one of these three lesions viz., single CT enhancing lesion, single small cerebral calcific CT lesion, and multiple small cerebral calcific CT lesions ${ }^{17}$. NCC, single CT enhancing lesion and small single cerebral calcific CT lesion together accounted for $40 \%$ of etiological factors of seizure as reported in a retrospective study by the same group from India $^{18}$. Extraparenchymal NCC is rare in children and carries a poor prognosis $^{29}$. Also, no extraparenchymal cysticercosis was reported in the present series. However, frequent reporting of cysticercosis in eyes, from the same region of this country indicates the possible prevalence of cysticercosis in children ${ }^{18}$.

This is the first report of cysticercal etiology of childhood epilepsy from this particular territory. There were a few earlier reports from other provinces in the country showing a similar occurrence of cysticercal etiology of childhood seizure ${ }^{11,33}$. NCC has been diagnosed on imaging studies in $34.6 \%$ of patients with seizure disorder of any type, $59.2 \%$ of those with a single seizure, $23.7 \%$ of those with recurrent seizure disorder as reported in a recent review ${ }^{27}$. In the present study, $\mathrm{NCC}$ is found to be the etiologic factor in $37.7 \%$ among the patients presenting with seizures and we did not include any adult case in this survey. The majority of our patients were drawn from the rural population with agriculture and animal farming background. Analysis based on earlier studies indicates that NCC should be suspected in every child with seizures and seroepidemiological study may be concluded for the ultimate control of the disease ${ }^{26}$. Thus, NCC must be considered in the differential diagnosis of seizures and a wide variety of neurologic disorders, particularly in endemic areas ${ }^{29}$. We analyzed the social customs and related factors which are peculiar to this region and were indirectly responsible for the high incidence of cysticercosis (data not presented). Usually, the highest prevalence rates exist in communities where there is close contact between man and pigs, hygienic standards are low, and pork is eaten as raw or undercooked. In Southern India, NCC was found in $2.2 \%$ of epilepsy cases. A study from Northern India indicated that cerebral cysticercosis was found in $11.1 \%$ amongst those attending the neurology clinic and $17.4 \%-19.2 \%$ of clinically suspected patients. An earlier study from endemic villages report up to $10 \%$ or more of the general population having antibodies to $T$. solium, not necessarily reflecting the true prevalence of the cysticercosis and leading to misdiagnosis in a proportion of neurological cases ${ }^{2}$. So, a community approach may help with estimating the true prevalence of cysticercosis.

Sensitivity and specificity of the presently used commercial ELISA 


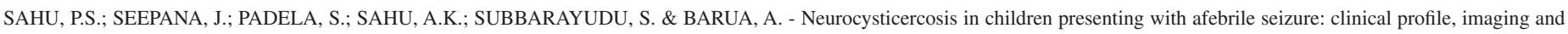
serodiagnosis. Rev. Inst. Med. Trop. Sao Paulo, 56(3): 253-8, 2014.

in serum reported to be $85 \%$ and $94 \%$ respectively in our previous study $^{25}$. In another Indian study, ELISA kit from the same manufacturer was reported to be of similar sensitivity and specificity ${ }^{3}$. Previously we demonstrated $80 \%$, and $90 \%$ sensitivity of in-house dot-ELISAs when $T$. solium metacestode somatic, and ES respectively were used (data unpublished). Specificities of this in house Dot-ELISAs using T. solium metacestode somatic and ES antigens were observed to be $90 \%$ in each case. Sensitivity of the employed ELISA kit for anti-Cysticercus antibody detection as previously estimated was based on results of the test using sera from cases with a definitive diagnosis of $\mathrm{NCC}^{25}$. However, in the present study the test was employed to screen for anti-Cysticercus antibody in serum from patients presenting with afebrile seizure and in all suspected cases without any definitive diagnosis of NCC. Hence in the present screening study, we could diagnose only $37.7 \%$ cases to be positive for the said ELISA test. It is also true that the rest of the cases were negative for the anti-Cysticercus antibody which means the underlying cause of NCC in those cases could not be established otherwise possibly there may be other etiology in those cases. However, the importance of NCC as one of the underlying causes of acute afebrile seizure in pediatric patients could be highlighted in our study.

Usually, determination of the prevalence of an infection is hampered by variable sensitivity and specificity of each of the diagnostic tests used, which identify a limited or overlapping proportion of its true prevalence. There may be discrepancy between radio-imaging based on suspicion of NCC vs. a serological test result. The majority of NCC cases do not always show typical neuro-imaging features and solitary brain lesion which is a diagnostic challenge ${ }^{10}$. Hence it is important for the clinician to choose an appropriate imaging modality for a proper diagnosis of the etiology in seizure patients. Sensitivity of a test detecting antibodies for the parasite is also related to the number of lesions present on the brain as found in our study. There was a statistically significant association found between the cases with multiple lesions in brain and the ELISA-positivity $(p=0.017)$. It may be due to a release of more antigens from multiple larvae that results in mounting a stronger antibody response in the infected host as suggested in a recent article ${ }^{36}$.

The presence of antibodies was assessed among all the cases either having intracranial lesion or no lesion after brain imaging; it was done to employ the use of serological investigation in the diagnosis of NCC before using imaging. The one child who had no abnormality on their brain CT but was found to be ELISA positive was of interest. This child responded to the albendazole therapy and after follow up, there was a significant decrease in antibody titre for the above case (data not shown). However, it could only support the fact that the studied population had an exposure to the parasite. However, detection of antibodies with a different rationale may be considered indicative of the active infection. An early and appropriate diagnosis, revealing the biological stage of the parasite would be of value in initiating an appropriate treatment. Moreover, it would be useful in population screening, diagnosis and post-treatment monitoring of NCC especially in the situations where imaging techniques are either not available or inconclusive.

\section{LIMITATION}

The prevalence of anti-Cysticercus antibodies detected in sera from the randomly selected children with afebrile seizure may not be the true picture if the figures are extrapolated to a larger population in the territory. The kit detects antibodies against antigens of the parasite which are not defined. Further study should be conducted to screen antibodies specific to more defined antigens of the larval parasite.

\section{CONCLUSION}

Detecting anti-Cysticercus IgG antibodies in serum could reveal the potentiality of possible NCC as an underlying cause of afebrile seizures in the studied pediatric cases. Although, the CT scan is a potent diagnostic tool compared to antibody detection, the diagnostic decision can be better made when both the modalities are considered together. Nevertheless NCC may be suspected as one of the major etiology and hence should be ruled out in every afebrile seizures case, with or without a radioimaging supportive diagnosis, especially in areas endemic for taeniasis/cysticercosis.

\section{RESUMO}

\section{Neurocisticercose em crianças apresentando crises afebris: perfil clínico, imagem e sorodiagnóstico}

Neurocisticercose é uma das causas mais comuns de crises em crianças em países em desenvolvimento incluindo Índia e América Latina. Neste estudo casos neurológicos pediátricos, apresentando crises afebris foram selecionados através de anticorpos anti-Cysticercus ( $\mathrm{IgG}$ ) no seu soro para avaliar possível etiologia de Cysticercus. O estudo incluiu total de 61 casos pediátricos de indivíduos com crises afebris (idade de um a 15 anos); houve predominância de pacientes do sexo masculino. Todos os soros foram testados usando um kit comercial IgG-ELISA (UB-Magiwell Cysticercosis kit ${ }^{\mathrm{TM}}$ ) avaliado previamente. $\mathrm{O}$ anticorpo anti-Cysticercus no soro foi positivo em 23 de 61 casos $(37,7 \%)$. A maioria dos casos com teste de ELISA positivo apresentava crises generalizadas $(52,17 \%)$, seguida por casos de crises parciais complexas $(26,08 \%)$ e crises parciais simples $(21,73 \%)$. Dores de cabeça foram a queixa principal $(73,91 \%)$. Outras manifestações foram vômitos $(47,82 \%)$, palidez $(34,78 \%)$, sensório alterado $(26,08 \%)$ e fraqueza muscular $(13,04 \%)$. Houve um caso de hemiparesia diagnosticado como NCC. Neste estudo uma criança sem quaisquer achados significantes às imagens apresentou sorologia positiva. Houve associação estatística significante entre os casos com múltiplas lesões no cérebro e a positividade pelo ELISA $(p=0,017)$. No seu conjunto a positividade pelo ELISA demonstra etiologia potencial para a cisticercose. Portanto neurocisticercose deve ser suspeitada em qualquer criança apresentado crises afebris com imagem que sugira diagnóstico em países tropicais em desenvolvimento ou em áreas endêmicas para teníase/cisticercose.

\section{ACKNOWLEDGEMENTS}

Hereby Dr Nalinikanta Panigrahy (Consultant Pediatrician) is sincerely acknowledged for helpful discussions during patient classification. The authors also acknowledge the contribution by Mrs. Madhusmita Sahu during reference work and data analysis. This work was partly supported by the Indian council of Medical Research under ICMR Short Term Research Studentship-Grant to J Seepana during her Undergraduate studies in Medicine. 
SAHU, P.S.; SEEPANA, J.; PADELA, S.; SAHU, A.K.; SUBBARAYUDU, S. \& BARUA, A. - Neurocysticercosis in children presenting with afebrile seizure: clinical profile, imaging and serodiagnosis. Rev. Inst. Med. Trop. Sao Paulo, 56(3): 253-8, 2014.

\section{AUTHORS' CONTRIBUTION}

Experiments conceived and designed by: PS Sahu, AK Sahu. Experiments performed by: PS Sahu, J Seepana. Data Analyzed by: PS Sahu, A Barua. Contributed cases and clinical specimens: S Padela, AK Sahu, S Subbarayudu. Authors of the paper: PS Sahu, J Seepana, AK Sahu.

\section{REFERENCES}

1. Balaji J. Clinical and radiological profile of neurocysticercosis in South Indian children. Indian J Pediatr. 2011;78:1019-20.

2. Bern C, Garcia HH, Evans C, Gonzalez AE, Verastegui M, Tsang VC, et al. Magnitude of the disease burden from neurocysticercosis in a developing country. Clin Infect Dis. 1999;29:1203-9.

3. Biswas R, Parija SC, Narayan SK. Dot-ELISA for the diagnosis of neurocysticercosis. Rev Inst Med Trop Sao Paulo. 2004;46:249-52.

4. Del Brutto OH, Rajshekhar V, White AC Jr, Tsang VC, Nash TE, Takayanagui OM, et al. Proposed diagnostic criteria for neurocysticercosis. Neurology. 2001;57:177-83.

5. Del Brutto OH. Diagnostic criteria for neurocysticercosis, revisited. Pathog Glob Health. 2012;106:299-304.

6. Del Brutto $\mathrm{OH}$. Neurocysticercosis in a 2-year-old boy infected at home. Pathog Glob Health. 2012;106;122-3.

7. Fleury A, Bouteille B, Garcia E, Marquez C, Preux PM, Escobedo F, et al. Neurocysticercosis: validity of ELISA after storage of whole blood and cerebrospinal fluid on paper. Trop Med Int Health. 2001;6:688-93.

8. Gaffo AL, Guillén-Pinto D, Campos-Olazábal P, Burneo JG. Cisticercosis como causa principal de crisis parciales en niños en Perú. Rev Neurol. 2004;39:924-6.

9. Garcia HH, Parkhouse RM, Gilman RH, Montenegro T, Bernal T, Martinez SM, et al. Serum antigen detection in the diagnosis, treatment, and follow-up of neurocysticercosis patients. Trans R Soc Trop Med Hyg. 2000;94:673-6.

10. Giri S, Parija SC. A review on diagnostic and preventive aspects of cystic echinococcosis and human cysticercosis. Trop Parasitol. 2012: 2:99-108.

11. Hussain J, Srinivasan S, Serane VT, Mahadevan S, Elangovan S, Bhuvaneswari V. Cranial computed tomography in partial motor seizures. Indian J Pediatr. 2004;71:641-4.

12. Kalra V, Suri M, Jailkhani BL. A profile of childhood neurocysticercosis. Indian J Pediatr. $1994 ; 61: 33-42$

13. Madigubba S, Vishwanath K, Reddy G, Vemuganti GK. Changing trends in ocular cysticercosis over two decades: an analysis of 118 surgically excised cysts. Indian J Med Microbiol. 2007;25:214-9.

14. Malla N, Kaur M, Kaur U, Ganguly NK, Mahajan RC. Evaluation of enzyme linked immunosorbent-assay for the detection of anticysticercus antibodies in cerebrospinal fluid from patients with neurocysticercosis. J Hyg Epidemiol Microbiol Immunol. 1992;36:181-90.

15. Marquez-Monter H. Cysticercosis. In: Marcial-Rojas RA, editor. Pathology of protozoal and helminthic diseases. Baltimore: Williams \& Wilkins; 1971. p. 592-617.

16. Mohanty S, Deb M, Aggarwal P. Neurocysticercosis in a north Indian hospital. Trop Doct. 2008;38:177-9.

17. Murthy JM, Yangala R. Etiological spectrum of localization-related epilepsies in childhood and the need for $\mathrm{CT}$ scan in children with partial seizures with no obvious causation: a study from south India. J Trop Pediatr. 2000;46:202-6.
18. Murthy JM, Yangala R. Etiological spectrum of symptomatic localization related epilepsies: a study from South India. J Neurol Sci. 1998;158:65-70.

19. Murthy R, Samant M. Extraocular muscle cysticercosis: clinical features and management outcome. Strabismus. 2008;16:97-106.

20. Pal DK, Carpio A, Sander JW. Neurocysticercosis and epilepsy in developing countries J Neurol Neurosurg Psychiatry. 2000;68:137-43.

21. Pozo-García MP, Campos-Olazábal P, Burneo J. Neurocisticercosis en una población pediátrica en Lima: analisis epidemiológico y clínico. Rev Neurol. 2003;36:205-8.

22. Prasad KN, Prasad A, Verma A, Singh AK. Human cysticercosis and Indian scenario: a review. J Biosci. 2008;33:571-82.

23. Rajshekhar V, Joshi DD, Doanh NQ, van De N, Xiaonong Z. Taenia solium taeniosis/ cysticercosis in Asia: epidemiology, impact and issues. Acta Trop. 2003;87:53-60.

24. Sáenz B, Ruíz-Garcia M, Jiménez E, Hernández-Aguilar J, Suastegui R, Larralde C, $e$ al. Neurocysticercosis: clinical, radiologic, and inflammatory differences between children and adults. Pediatr Infect Dis J. 2006;25:801-3.

25. Sahu PS, Parija SC, Narayan SK, Kumar D. Evaluation of an IgG-ELISA strategy using Taenia solium metacestode somatic and excretory-secretory antigens for diagnosis of neurocysticercosis revealing biological stage of the larvae. Acta Trop. 2009;110:38-45.

26. Sharma P, Ganguly NK, Mahajan RC, Malla N. Clinical and laboratory analysis of neurocysticercosis in children. Indian J Med Microbiol. 1995;13:92-4

27. Singh G, Singh P, Singh I, Rani A, Kaushal S, Avasthi G. Epidemiologic classification of seizures associated with neurocysticercosis: observations from a sample of seizure disorders in neurologic care in India. Acta Neurol Scand. 2006;113:233-40.

28. Singhi P, Ray M, Singhi S, Khandelwal N. Clinical spectrum of 500 children with neurocysticercosis and response to albendazole therapy. J Child Neurol. 2000;15:20713

29. Singhi P, Singhi S. Neurocysticercosis in children. J Child Neurol. 2004;19:482-92.

30. Singhi P. Infectious causes of seizures and epilepsy in the developing world. Dev Med Child Neurol. 2011;53:600-9.

31. Singhi PD, Baranwal AK. Single small enhancing computed tomographic lesions in Indian children. II. Clinical features, pathology, radiology and management. J Trop Pediatr. 2001;47:266-70.

32. Talukdar B, Saxena A, Popli VK, Choudhury V. Neurocysticercosis in children: clinical characteristics and outcome. Ann Trop Paediatr. 2002;22:333-9.

33. Thakur LC, Anand KS. Childhood neurocysticercosis in south India. Indian J Pediatr. 1991;58:815-9

34. Udani V. Pediatric epilepsy: an Indian perspective. Indian J Pediatr. 2005;72:309-13.

35. White AC Jr. Neurocysticercosis: a major cause of neurological disease worldwide. Clin Infect Dis. 1997;24:101-13

36. Zea-Vera A, Cordova EG, Rodriguez S, Gonzales I, Pretell EJ, Castillo Y, et al. Parasite antigen in serum predicts the presence of viable brain parasites in patients with apparently calcified cysticercosis only. Clin Infect Dis. 2013;57:e154-9.

Received: 26 November 2012

Accepted: 4 October 2013 